\title{
A previously unclassified trypanosomatid responsible for human cutaneous lesions in Martinique (French West Indies) is the most divergent member of the genus Leishmania ss
}

\author{
H. NOYES ${ }^{1 *}$, F. PRATLONG ${ }^{2}$, M. CHANCE${ }^{3}$, J. ELLIS ${ }^{4}$, G. LANOTTE ${ }^{2}$ and J.-P. DEDET ${ }^{2}$ \\ ${ }^{1}$ School of Biological Sciences, University of Liverpool, Liverpool L69 7ZD, UK \\ ${ }^{2}$ Laboratoire de Parasitologie and Centre National de Référence des Leishmania, 163 Rue Auguste Broussonet, \\ F-34090 Montpellier, France \\ ${ }^{3}$ Liverpool School of Tropical Medicine, Pembroke Place, Liverpool L3 5QA, UK \\ ${ }^{4}$ Department of Cell and Molecular Biology, University of Technology, Sydney NSW 2065, Australia
}

(Received 1 Fune 2001 ; revised 3 August 2001; accepted 6 August 2001)

\begin{abstract}
S U M M A R Y
Two cases of skin lesions similar to those caused by Leishmania parasites have been reported from Martinique. Parasites isolated from these lesions were unlike Leishmania reference strains by isoenzyme analysis and electron microscopy and were assumed to be monoxenous trypanosomatids which normally only infect invertebrates. Both strains have now been retyped by isoenzyme analysis and found to be identical to each other and distantly related to all other Leishmania species. The sequence of the 18S ribosomal RNA gene and partial sequences of the DNA polymerase alpha and RNA polymerase II largest subunit genes were obtained. These sequences indicated that the Martinique parasites clustered with L. enriettii and were basal to all other euleishmania. However, support for both the position basal to all euleishmania and the clustering with L. enriettii was low. The Martinique parasites may cluster with L. (Leishmania) or L. (Viannia) or form a novel clade within the euleishmania either with or without L. enriettii.
\end{abstract}

Key words: leishmaniasis, Antilles, Trypanosomatidae, cutaneous leishmaniasis, taxonomy.

\section{INTRODUCTION}

There have been occasional reports of leishmaniasis like infections in Martinique since 1917. The first parasites to be isolated and identified by isoenzyme electrophoresis were from an HIV-infected patient. These parasites were found to be quite unlike any other species of Leishmania by isoenzyme analysis and electron microscopy (EM) (Dedet et al. 1995). The application of EM showed that the morphology of these organisms was more characteristic of monoxenous trypanosomatids. It was consequently concluded that the HIV infection had made the patient susceptible to a monoxenous parasite of invertebrates that would not normally infect humans or other mammals. Subsequently another strain was isolated from a localized cutaneous lesion in an HIVnegative patient, living on the same island of Martinique. This parasite belonged to the same zymodeme as the one that had been isolated from the immunocompromised patient (Boisseau-Garsaud et al. 2000). There have also been reports of other cases

* Corresponding author: Donnan Laboratory, School of Biological Sciences, University of Liverpool, Liverpool L69 7ZD, UK. Tel +44 151794 3627. Fax +44 151794 3655. E-mail: harry@liv.ac.uk of human and mammalian infections with what appear to be monoxenous trypanosomatids (Schnur et al. 1992; Jimenez et al. 1996; Pacheco et al. 1998; Sousa et al. 1998). Three hypotheses may explain such observations: (1) a novel group or groups of digenetic trypanosomatids exist that can infect humans, (2) some humans are susceptible to occasional infections by normally monoxenous trypanosomatids and (3) the parasites have been incorrectly reported to be a lower trypanosomatid.

In order to test these alternative hypotheses we have classified both of the unusual parasites from Martinique using isoenzymes and one of them with the partial sequences of the RNA polymerase, DNA polymerase and small subunit ribosomal RNA genes. All these methods show that the Martinique parasites are not closely related to any genus of monoxenous trypanosomatid but are highly divergent members of the genus Leishmania.

MATERIALS AND METHODS

\section{Strains studied}

The 2 strains obtained from the Martinique patients are MHOM/MQ/92/MAR1 and MHOM/MQ/ 
Table 1. Taxa, zymodemes and WHO code numbers of the 49 reference strains used for isoenzyme analysis

\begin{tabular}{|c|c|c|}
\hline Species complex & Taxon and zymodeme & $\begin{array}{l}\text { Zymodeme reference strain } \\
\text { (WHO code) }\end{array}$ \\
\hline L. (L.) aethiopica & $\begin{array}{l}\text { L. aethiopica MON-14 } \\
\text { L. aethiopica MON-69 } \\
\text { L. aethiopica MON-70 }\end{array}$ & $\begin{array}{l}\text { MHOM/ET/72/L100 } \\
\text { MHOM/ET/82/101-82 } \\
\text { MHOM/ET/83/68-83 }\end{array}$ \\
\hline L. (L.) turanica & $\begin{array}{l}\text { L. turanica MON-21 } \\
\text { L. turanica } \mathrm{MON}-64\end{array}$ & $\begin{array}{l}\text { MRHO/SU/65/VL } \\
\text { MRHO/SU/74/95A }\end{array}$ \\
\hline L. (L.) major & $\begin{array}{l}\text { L. major } \mathrm{MON}-25 \\
\text { L. major } \mathrm{MON}-26\end{array}$ & $\begin{array}{l}\text { MHOM/MA/81/LEM265 } \\
\text { MHOM/YD/76/LEM62 }\end{array}$ \\
\hline L. (L.) tropica & $\begin{array}{l}\text { L. tropica MON-5 } \\
\text { L. tropica } \mathrm{MON}-7\end{array}$ & $\begin{array}{l}\text { MRAT/IQ/72/ADHANIS } \\
\text { MHOM/PK/00/LV691 }\end{array}$ \\
\hline L. (L.) killicki & L. killicki MON-8 & MHOM/TN/80/LEM163 \\
\hline L. (L.) donovani & $\begin{array}{l}\text { L. donovani } \mathrm{MON}-2 \\
\text { L. donovani MON-18 }\end{array}$ & $\begin{array}{l}\text { MHOM/IN/00/DEVI } \\
\text { MHOM/ET/67/HU3 }\end{array}$ \\
\hline L. (L.) infantum & $\begin{array}{l}\text { L. infantum MON-1 } \\
\text { L. infantum MON-30 } \\
\text { L. mexicana MON-40 }\end{array}$ & $\begin{array}{l}\text { MHOM/FR/78/LEM75 } \\
\text { MHOM/SD/82/GILANI } \\
\text { MYNC/BZ/62/M379 }\end{array}$ \\
\hline L. (L.) mexicana & $\begin{array}{l}\text { L. mexicana } \mathrm{MON}-121 \\
\text { L. mexicana } \mathrm{MON}-152 \\
\text { L. mexicana } \mathrm{MON}-156\end{array}$ & $\begin{array}{l}\text { MHOM/MX/89/RIOS } \\
\text { MHOM/MX/85/SOLIS } \\
\text { MHOM/BZ/BEL21 }\end{array}$ \\
\hline L. (L.) amazonensis & $\begin{array}{l}\text { L. amazonensis } \mathrm{MON}-41 \\
\text { L. amazonensis MON-132 } \\
\text { L. amazonensis MON-157 } \\
\text { L. aristedesi MON-133 }\end{array}$ & $\begin{array}{l}\text { IFLA/BR/67/PH8 } \\
\text { MHOM/BR/73/M2269 } \\
\text { IFLA/TT/71-110 } \\
\text { MORY/PA/68/GML-3 }\end{array}$ \\
\hline L. (L.) enriettii & $\begin{array}{l}\text { L. enriettii MON-97 } \\
\text { L. enriettii MON-227 }\end{array}$ & $\begin{array}{l}\mathrm{MCAV} / \mathrm{BR} / 45 / \mathrm{L} 88 \\
\mathrm{MCAV} / \mathrm{BR} / 95 / \mathrm{CUR} 3\end{array}$ \\
\hline L. (V.) guyanensis & $\begin{array}{l}\text { L. guyanensis } \mathrm{MON}-45 \\
\text { L. guyanensis MON-143 }\end{array}$ & $\begin{array}{l}\text { MHOM/GF/79/LEM85 } \\
\text { MHOM/EC/90/AR032 }\end{array}$ \\
\hline L. (V.) panamensis & $\begin{array}{l}\text { L. panamensis } \mathrm{MON}-47 \\
\text { L. panamensis } \mathrm{MON}-51 \\
\text { L. panamensis } \mathrm{MON}-124\end{array}$ & $\begin{array}{l}\mathrm{MHOM} / \mathrm{PA} / 75 / \mathrm{M} 4037 \\
\mathrm{MHOM} / \mathrm{CO} / 83 / \mathrm{REST} 417 \\
\mathrm{MHOM} / \mathrm{CO} / 88 / \mathrm{UA} 264\end{array}$ \\
\hline L. (V.) shawi & L. shawi $\mathrm{MON}-144$ & MCEB/BR/84/M8408 \\
\hline L. (V.) braziliensis & $\begin{array}{l}\text { L. braziliensis MON-43 } \\
\text { L. braziliensis MON-44 } \\
\text { L. braziliensis MON-141 } \\
\text { L. braziliensis MON-164 } \\
\text { L. braziliensis MON-166 } \\
\text { L. braziliensis MON-167 }\end{array}$ & $\begin{array}{l}\text { MHOM/BR/75/M2903 } \\
\text { MHOM/CO/83/LEM469 } \\
\text { MCAN/PE/91/LEM2222 } \\
\text { MHOM/CO/90/1257 } \\
\text { MHOM/BR/83/LTB300 } \\
\text { MHOM/BZ/81/BEL6 }\end{array}$ \\
\hline L. (V.) peruviana & $\begin{array}{l}\text { L. peruviana MON-127 } \\
\text { L. peruviana MON-128 } \\
\text { L. peruviana MON-142 } \\
\text { L. peruviana MON-177 }\end{array}$ & $\begin{array}{l}\text { MHOM/PE/84/LC26 } \\
\text { MHOM/PE/84/UN59 } \\
\text { MHOM/PE/84/CE49 } \\
\text { MRAT/PE/84/A3 }\end{array}$ \\
\hline L. (V.) naiffi & $\begin{array}{l}\text { L. naiffi MON-148 } \\
\text { L. naiffi MON-193 } \\
\text { L. naiffi MON-254 }\end{array}$ & $\begin{array}{l}\text { MDAS/BR/79/M5533 } \\
\text { MHOM/00/94/CRE54 } \\
\text { MHOM/GF/97/CRE88 }\end{array}$ \\
\hline L. hertigi & $\begin{array}{l}\text { L. hertigi } \mathrm{MON}-135 \\
\text { L. deanei MON-52 } \\
\text { L. deanei MON-134 }\end{array}$ & $\begin{array}{l}\mathrm{MCOE} / \mathrm{PA} / 65 / \mathrm{C} 8 \\
\mathrm{MCOE} / \mathrm{BR} / 74 / \mathrm{M} 5088 \\
\mathrm{MCOE} / \mathrm{BR} / 74 / \mathrm{M} 2674\end{array}$ \\
\hline L. (V.) lainsoni & $\begin{array}{l}\text { L. lainsoni MON-149 } \\
\text { L. lainsoni MON-150 } \\
\text { L. lainsoni MON-151 }\end{array}$ & $\begin{array}{l}\text { MHOM/BR/81/M6426 } \\
\text { IUBI/BR/00/M12025 } \\
\text { MCUN/BR/85/M9342 }\end{array}$ \\
\hline
\end{tabular}

97/MAR2. For isoenzyme analysis they were both compared to 49 zymodemes chosen from reference strains (Table 1); 14 of which were from the Old World and 35 from the New World.
Isoenzyme analysis

Starch gel electrophoresis was performed according to the method described by Rioux et al. (1990) using 
the following 13 enzyme systems: malic enzyme (ME), EC 1.1.1.40; isocitrate dehydrogenase (ICD), EC 1.1.1.42; 6-phosphogluconate dehydrogenase (PGD), EC 1.1.1.44; glucose 6-phosphate dehydrogenase (G6PD), EC 1.1.1.49; NADH diaphorase (DIA), EC 1.6.2.2; purine nucleoside phosphorylase1 $\left(\mathrm{NP}_{1}\right)$, EC 2.4.2.1; purine nucleoside phosphorylase $2\left(\mathrm{NP}_{2}\right)$, EC 2.4.2*; glutamate oxaloacetate transaminase 1 and $2\left(\mathrm{GOT}_{1}\right.$ and $\left.\mathrm{GOT}_{2}\right), \mathrm{EC}$ 2.6.1.1; phosphoglucomutase (PGM) EC 5.4.2.2; fumarate hydratase $(\mathrm{FH})$ EC 4.2.1.2; mannose phosphate isomerase (MPI) EC 5.3.1.8; glucose phosphate isomerase (GPI), EC 5.3.1.9. Iso-electrofocussing was also used since it has greater resolving power (Piarroux et al. 1994).

\section{Cladistic analyses}

For the taxonomic study, 50 operational taxonomic units (OTU) were used which represented a comprehensive range of the most important zymodemes. Thirty-five zymodemes were from the phylogenetic complexes of New World as defined by Rioux \& Lanotte (1993): 6 L. guyanensis, 10 L. braziliensis, 3 L. naiffi, 3 L. hertigi, 3 L. lainsoni, 4 L. mexicana, 4 L. amazonensis and 2 L. enriettii. Fourteen zymodemes were from the phylogenetic complexes of the Old World: 3 L. aethiopica, 2 L. turanica, 2 L. major, 2 L. tropica, 1 L. killicki, 2 L. donovani, 2 L. infantum, the zymodeme MON-229, corresponding to the enzyme profile of the 2 strains of the Martinique island.

The cladogram construction was based on Hennig's (1965) principles and used the MIX program in PHYLIP (Felsenstein, 1988).

\section{Molecular phylogeny}

DNA was prepared by proteinase K, SDS lysis, phenol-chloroform extraction and ethanol precipitation. The $18 \mathrm{~S}$ rDNA alignment was compiled using published sequences from GenBank with the addition of the sequences of $L$. hertigi and MAR1. The 18S rDNA of $L$. hertigi and MAR1 were amplified by PCR and the PCR products were directly sequenced in both directions using the primers described by Maslov et al. (1996) on an ABI 377 using Big Dye chemistry (Advanced Biosystems). The sequences were aligned using the PILEUP program in GCG and adjusted by eye to remove ambiguities. Sequence regions that were present in only a minority of species or that could not be aligned with confidence were deleted to give an overall aligned sequence length of $1811 \mathrm{bp}$.

RNA polymerase II largest subunit sequences of MAR1 and L. enriettii were amplified by PCR and directly sequenced using the primers of Croan, Morrison \& Ellis (1997) (RPOF1 5'GTAAGCGAGCCAGGTGT; RPO-R1 5'GCAGCCGCACAA-
TGCGCT; the sequence of RPO-F1 given here is different from that of Croan et al. (1997) where it was incorrectly reported.) The following 3 combinations of sequencing primers were also used (the position of the primers in the sequence of the $L$. donovani RNA polymerase gene GenBank accession number AF126254 is indicated after the sequence of each primer). (1) PRO-1F (GACACAGCCGTCAAGAC; > 2512-2528); RPO-2R (CTGCAGCTCCCGCAC < 3051-3031); (2) RPO-3F (CAC(G/A)AC(G/A)ATGGGTAAGC > 2966-2983); RPO-4R((A/G)AT(A/G)AACTGCTG $(\mathrm{C} / \mathrm{T}) \mathrm{GCCTC}<$ 3504-3487); (3) ROP-5F (CAGCAGTC(C/A)CTCATCACC > 3253-3270); ROP-6R (GCAGCCGCACAATGC < 3800-3814).

This strategy yielded the full length of the RNA polymerase II fragment used by Croan et al. (1997) of L. enriettii but failed to amplify the $5^{\prime}$ end of the MAR1 sequence. Consequently the RNA polymerase II alignment corresponds to positions 4911248 of the RNA polymerase II alignment used by Croan et al. (1997). The complete sequence of the DNA polymerase fragment used by Croan et al. (1997) was obtained for both L. enriettii and MAR1. The DNA polymerase gene was amplified with primers DPO1 (5' AACGAGCGCGCACTGCT) and DPO2 (5' GCCGAGGCAGCCATACAT) (Croan et al. 1997) and sequenced with these primers and internal sequencing primers L1023-F (AACCTGTGGAGCCGTAC 400-416 in AF009141) and L1023-R(GTAATGAACTT(A/G)AG(A/G)TCGTGG 488-468 in AF009141). The sequence of primer DPO1 given here is different from that reported by Croan et al. (1997) where it was incorrectly reported. The new sequences were aligned with the sequences of homologous genes submitted to GenBank by Croan et al. (1997) using the Clustal $\mathrm{V}$ option in the Megalign program (Higgins, Desmond \& Sharp, 1989; Saitou \& Nei, 1987). Regions that were not present in all taxa were deleted. The alignments of the RNA (758 bp) and DNA (915 bp) polymerase genes were combined to give a single data set for analysis as per Noyes et al. (2000) and a phylogeny was compiled using the DNAML maximum likelihood program in PHYLIP (Felsenstein, 1985).

\section{RESULTS}

\section{Isoenzyme analysis}

The 2 Martinique strains MAR1 and MAR2 studied presented the same enzyme profile, corresponding to a zymodeme numbered MON-229: $\mathrm{ME}^{45}, \mathrm{ICD}^{95}$, $\mathrm{PGD}^{87}, \mathrm{G} \mathrm{PD}^{78}, \mathrm{DIA}^{30}, \mathrm{NP}_{1}^{00}, \mathrm{NP}_{2}^{85}, \mathrm{GOT}_{1}^{170}$, $\mathrm{GOT}_{2}^{00}, \mathrm{PGM}^{104}, \mathrm{FH}^{65}, \mathrm{MPI}^{\mathrm{I3}}, \mathrm{GPI}^{52}$. With the exception of 2 isoenzymes $\left(\mathrm{NP}_{1}\right.$ and $\left.\mathrm{NP}_{2}\right)$, all the electromorphs are unique to the Martinique strains, demonstrating the extreme divergence of this zymodeme from all other Leishmania zymodemes. 


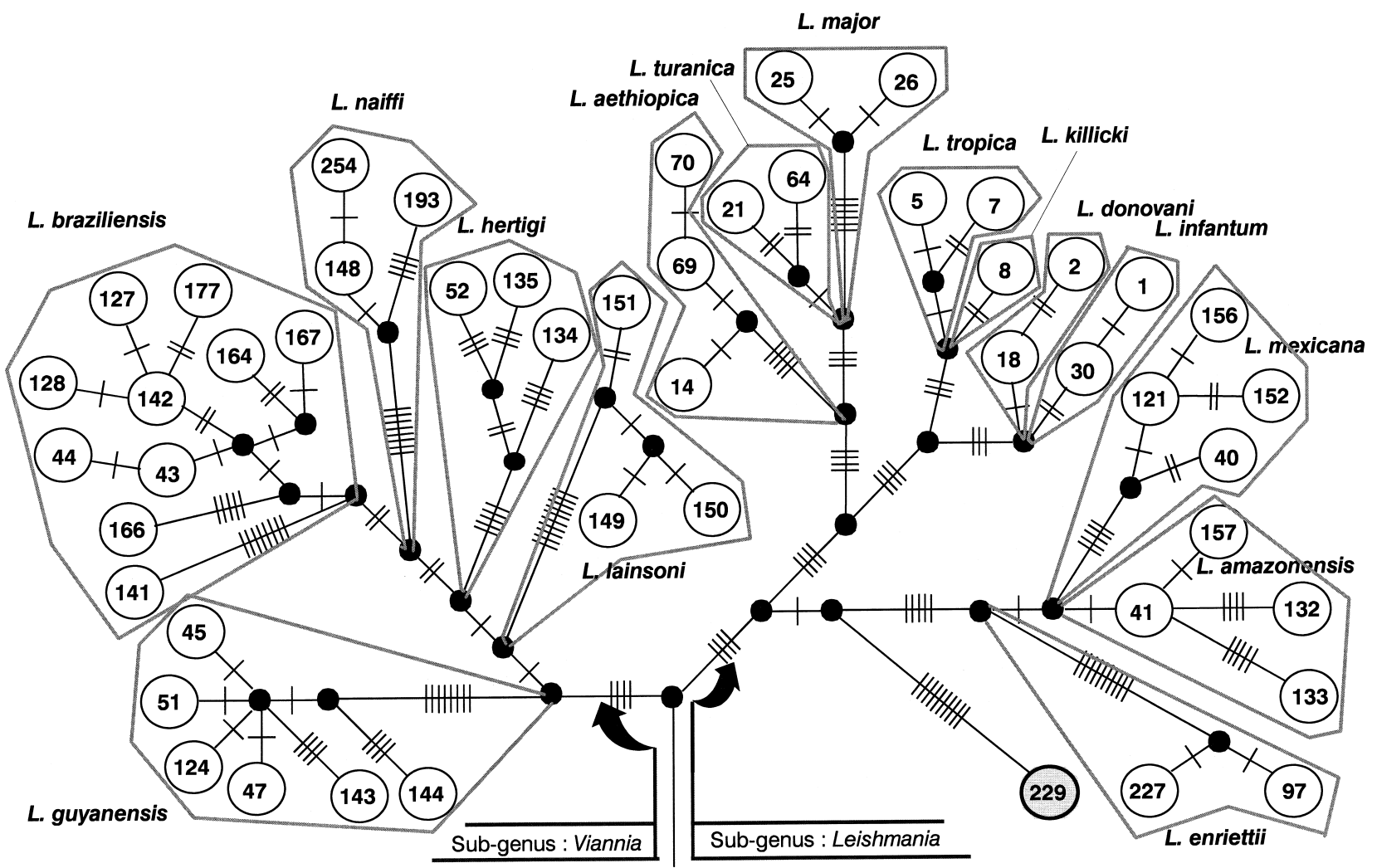

Fig. 1. Cladogram that includes 50 operational taxonomic units, corresponding to 35 New World zymodemes, 14 Old World zymodemes and the Martinique zymodeme MON-229. MON-229 appears clearly distant from other groups and is located at the base of the New World Leishmania (Leishmania) clusters. The numbers in the cladogram are the zymodeme numbers the names of species that are represented by zymodemes are indicated in Table 1.

The most parsimonious cladgram obtained with the 50 OTU has 213 evolutionary steps (Fig. 1). It is consistent with the cladogram obtained by Thomaz Soccol et al. (1993), and clearly shows the 2 subgenera L. (Leishmania) and L. (Viannia). The OTU MON-229 is located on the Leishmania subgenus branch, and more precisely at the base of the New World Leishmania cluster. It appears very distant from other groups of this cluster, including L. enriettii, L. mexicana, and L. amazonensis.

\section{$18 S$ rRNA sequence phylogeny}

A phylogeny of the 18s rRNA gene compiled using the parsimony program DNAPARS in the PHYLIP package showed the separation of the Leishmania species into 2 distinct clades. These 2 clades have been informally named (i), the paraleishmania which contain Endotrypanum monterogeii and L. hertigi, L. colombiensis, L. equatoriensis and L. herreri; and (ii) the euleishmania, containing representatives of the L. (Leishmania), L. (Viannia) and L. (Sauroleishmania) subgenera (Cupolillo et al. 2000). The sequence of the Martinique parasite MAR1 clustered in the euleishmania (Leishmania ss) clade (Fig. 2A).

The bootstrap support for the euleishmania in this phylogeny is only $60 \%$. A distance tree had the same topology but with slightly higher bootstrap support $(68 \%)$ for the euleishmania. Although the $18 \mathrm{~S}$ gene is not suitable for resolving relationships within the genus Leishmania this gene does suggest that MAR1 clusters with this genus of digenetic parasites.

\section{$R N A$ and DNA polymerase phylogeny}

The maximum likelihood phylogeny of the combined RNA and DNA polymerase data set had a topology identical to the published phylogeny of the DNA polymerase gene (Croan et al. 1997) (Fig. 2 B).

L. enriettii and MAR1 cluster together in $100 \%$ of bootstrap replicates and this clade was basal to all other euleishmania in $64 \%$ of bootstrap replicates; however, in $34 \%$ of bootstrap replicates they clustered with the L. (Leishmania)/L. (Sauroleishmania) clade. They also clustered with $L$. (Viannia) in $2 \%$ of trees. The distance matrix derived from the DNA and RNA polymerase genes (Table 2) gives some indications of why the position of the MAR1/L. enriettii clade in the maximum likelihood phylogeny is not highly supported. $L$. enriettii and MAR1 were more distant from each other (Kimura distance 0.1110) than any other pair of L. (Leishmania) and L. (Viannia) species (0.00480.0915). Mar1 is also the most divergent of all the euleishmania strains. It is because of the relatively large distances separating L. enriettii and MAR1 from all other euleishmania species that these 2 parasites cluster together and not because they are 
A

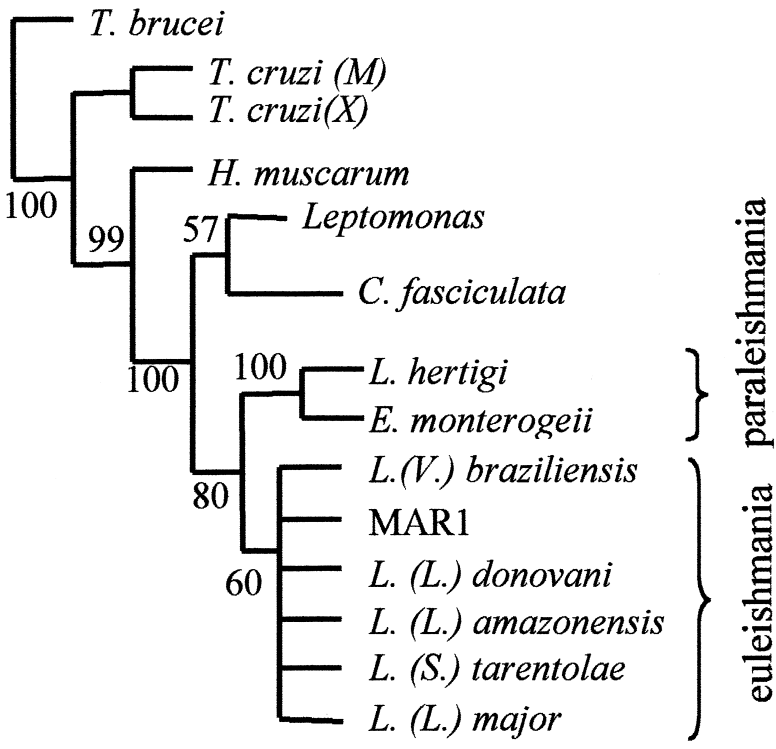

.10

B

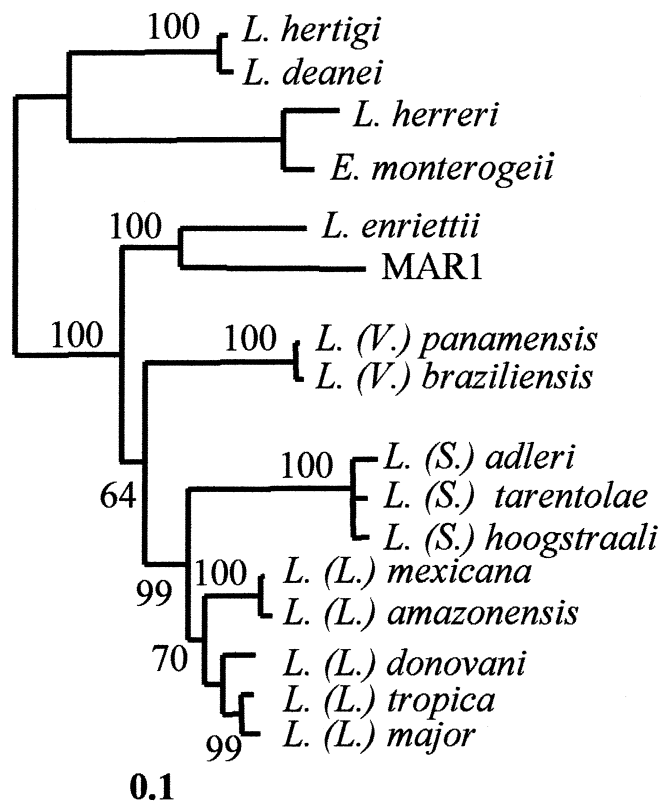

Fig. 2. (A) Unrooted tree produced from the $18 \mathrm{~S}$ rDNA sequence alignment by the DNAPARS programme in PHYLIP. GenBank accession number Leishmania (L.) major (X53915); L. (L.) amazonensis (X53912); L. (S.) tarentolae (X53916); L. (L.) donovani (X07773); L. (V.) braziliensis (M80292); L. hertigi (U59492); MHOM/MQ/92MAR1 (AF303938); Endotrypanum monterogeii (X53911); Crithidia fasciculata (X03450); Leptomonas spp. (X53914); Herpetomonas muscarum (L18872); Trypanosoma cruzi (X53917); T. сruzi (M31432); T. brucei (M12676). (B) Phylogenetic relationships among combined DNA polymerase Alpha catalytic subunit (915 nucleotides) and RNA polymerase II largest subunit (758 nucleotides) sequences from Endotrypanum and selected closely related to each other. In the distance matrix $L$. enriettii was slightly more closely related to the $L$. (Leishmania) subgenus $(0 \cdot 1008-0 \cdot 1078)$ than to MAR1 (0.1110). The low bootstrap support for the position of MAR1/L. enriettii clade relative to other euleishmania subgenera in the polymerase gene phylogeny is a consequence of this anomaly, which may be caused by different evolutionary rates in the different clades. Exclusion of L. enriettii had no effect either on the position of MAR1 or the bootstrap support for the other euleishmania.

\section{DISCUSSION}

The parasites in zymodeme MON-229 were isolated from 2 patients from Martinique Island. They were initially tentatively described as monoxenous trypanosomatids, since electron micrographs showed the presence of presumed opisthomastigote stages. This identification was supported by the fact that the isoenzymes show a parasite distinct from all known Old and New World Leishmania zymodemes (Dedet et al. 1995). The 18S rRNA and DNA and RNA polymerase phylogenies clearly indicate that MAR1 is a member of the genus Leishmania. All other members of this genus are either known or believed to be digenetic parasites of sandflies and mammals or reptiles, it is therefore likely that MAR1 is also a digenetic parasite of sandflies and vertebrates.

In the light of the $18 \mathrm{~S}$ rRNA, DNA polymerase and RNA polymerase data, the MON-229 zymodeme was incorporated into a cladistic analysis of the whole genus. The isoenzyme analyses presented here show that the MON-229 zymodeme is clearly distinct from all other Leishmania taxa. On the cladogram, it is located within the L. (Leishmania) subgenus. Within this subgenus, it shares a common origin with the other New World taxa, from which it follows a long divergent evolution. This long divergent evolution makes it difficult to be confident about the precise relationship of MON-229 with other clades. In principle a more slowly evolving marker such as the DNA and RNA polymerase genes would be expected to give a more robust phylogeny over these longer evolutionary distances. L. enriettii and MAR1 are the most basal members of the euleishmania in the DNA and RNA polymerase phylogenies. However, these gene phylogenies may

species of Leishmania. The branch lengths are drawn proportional to the evolutionary distances. Sequences are taken from Croan et al. (1997) except for the $L$. enriettii sequences (GenBank Accession Nos. AF151728 (DNA polymerase) and AF151727 (RNA polymerase)) and MAR1 sequences (GenBank accession numbers AF326982 (RNA polymerase) and AF326983 (DNA polymerase)). The numbers at the nodes show the bootstrap support for that node, based on 100 bootstrap replicates. 


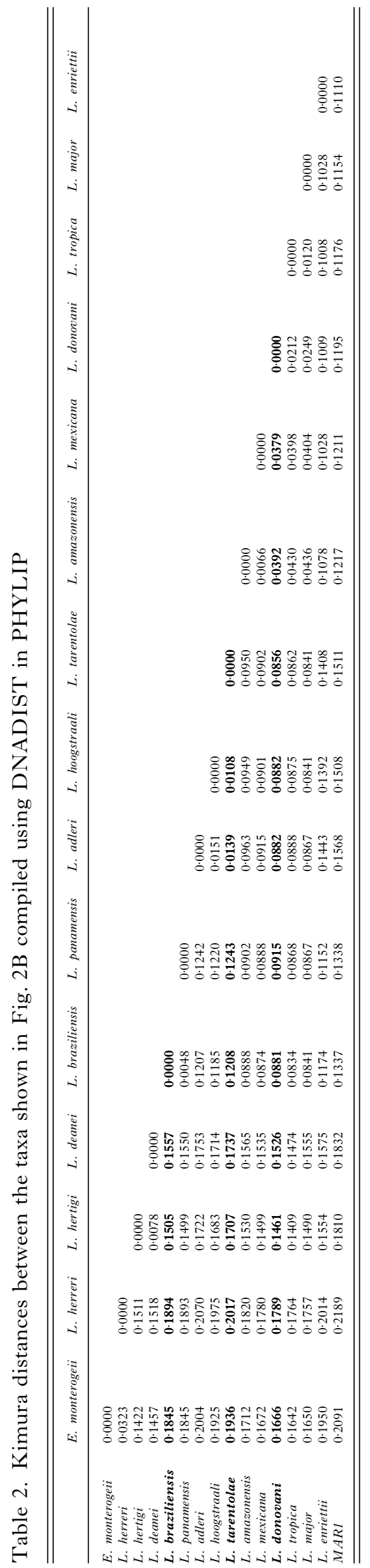

not reflect the parasites true phylogenies either, since the bootstrap support for this basal position is low. The position of the L. enriettii/MON-229 clade may be an artifact of Long Branch attraction and not a consequence of evolutionary history (Felsenstein, 1988). Although the classification of MON-229 remains uncertain it is clearly the most genetically divergent strain of euleishmania (Leishmania ss) that has been described to date. The distance matrices and the isoenzyme data indicate that both these parasites are most closely related to the $L$. (Leishmania) subgenus. Isoenzymes may be evolving too fast for the accurate classification of the L. enriettii/MON-229 clade within the genus Leishmania; however, the DNA and RNA polymerase genes may be evolving too slowly. A phylogeny of other genes that are evolving faster and that can be classified on the basis of amino acid sequence will be necessary to classify both $L$. enriettii and MON-229 parasites.

Other MON-229 like parasites may have been found

Prior to these 2 observations, 3 cases of autochthonous cutaneous leishmaniasis were reported from Martinique (Stevenel, 1917; Fouche \& Montestruc, 1951; Courmes et al. 1966). The parasitological diagnosis of these cases was based on the detection of amastigotes in skin smears. None of these parasites have been classified by modern methods that might indicate their relationships to other Leishmania species. The parasites were assumed to belong to the Leishmania genus on the basis of the clinical features of the lesions and the presence of amastigotes within the lesions. In the light of our observations on MAR1 and MAR2 it is possible that some or all of these cases are also due to zymodeme MON-229 like parasites.

\section{Ecology of MON-229}

The large genetic difference in the polymerase genes and the large phenotypic difference in the isoenzymes of MAR1 from other euleishmania are sufficient to warrant separate species status for these parasites. However, the authors believe that it is premature to describe a new species until more is known of the biology and ecology of MON-229 strains. At present nothing is known of the presumed reservoir hosts or sandfly vectors of MON-229 parasites. Lutzomyia atroclavatus is the only species of sandfly to have been reported from Martinique and is therefore a candidate vector (Fauran, Courmes \& Mille, 1966). All the indigenous mammalian fauna of Martinique is now extinct with the exception of bats. Bats are not known as reservoirs of Leishmania elsewhere so the most likely reservoir is perhaps an imported rodent. Leger reported finding a Leishmania like parasite in a lizard in Martinique in 1918. However, there are 
no proven records of lizard Leishmania from the New World despite some heroic searches and consequently this record has been dismissed by later reviewers (Telford, 1995). Therefore it seems unlikely that MAR1 is related to Leger's L. henrici or that lizards are the reservoir. The sequence data indicate that MAR1 is not closely related to Old World lizard Leishmania.

It has been shown that MAR1 and MAR2 produce disseminated but well-tolerated infections in Balb/C mice indicating that these parasites may be a valuable model for subclinical infections (Garin et al. 2001).

The other presumed monogenetic trypanosomatids that have been isolated from humans and other mammals have not been systematically classified. They have been presumed to be monogenetic parasites because they could not be positively identified as either Leishmania or Trypanosoma species. The data presented here show that it is essential to classify an unidentified parasite strain using an appropriate gene sequence, such as the $18 \mathrm{~S}$ gene, since the genus Leishmania appears to be more genetically diverse than had been anticipated.

The Centre National de Référence des Leishmania receives financial support from the Direction Générale de la Santé, Ministère de l'Emploi et de la Solidariré (Paris, France). The authors thank $\mathrm{Mr} \mathrm{P}$. Lami for expert technical assistance.

\section{REFERENCES}

Boisseau-Garsaud, a. M., Cales-Quist, D., Desbois, N., Jouannelle, J., JOUANNElle, A., PRATlong, F. \& DEDET, J. P. (2000). A new case of cutaneous infection by a presumed monoxenous trypanosomatid in the island of Martinique (French West Indies). Transactions of the Royal Society of Tropical Medicine and Hygiene 94, 51-52.

COURMES, E., ESCUdie, A., FAURAN, P. \& MONNERVIlle, A. (1966). Premier cas autochtone de leishmaniose viscérale humaine en Guadeloupe. Bulletin de la Société de Patholgie Exotique 59, 149-159.

CROAN, D. G., MORRISON, D. A. \& ElLIS, J. T. (1997). Evolution of the genus Leishmania revealed by comparison of DNA and RNA polymerase gene sequences. Molecular and Biochemical Parasitology 89, 149-159.

CUPolillo, E., Medina-Acosta, E., NOYes, H. A., MOMEN, H. \& GRIMALDI, G. Jr. (2000). A revised classification for Leishmania and Endotrypanum. Parasitology Today 16, 142-144.

Dedet, J. P., Roche, B., PRATlong, F., CAles-Quist, D., JOUANNElle, J., BENichou, J. C. \& HUERRE, M. (1995). Diffuse cutaneous infection caused by a presumed monoxenous trypanosomatid in a patient infected with HIV. Transactions of the Royal Society of Tropical Medicine and Hygiene 89, 644-646.

Fauran, P., COurmes, E. \& Mille, R. (1966). Note sur la prèsence en Martinique de Phlebotomus atroclavatus (Diptera, Psychodidae). Bulletin de la Société de Patholgie Exotique 59, 904-907.
Felsenstein, J. (1985). Phylogenies and the comparative method. The American Naturalist 125, 1-15.

felsenstein, J. (1988). Phylogenies from molecular sequences: inference and reliability. Annual Review of Genetics 22, 521-565.

Fouche, v. \& MONTESTRUC, L. (1951). Un cas de leishmaniose américaine cutanée. Archives de l'Institut Pasteur de Martinique 4, 12-13.

Garin, Y. J. F., SUlahian, A., Meneceur, P., Pratlong, F., PRina, E., GANGNeuX, J. P., DEdet, J. P. \& DERouin, F. (2001). Experimental pathogenicity of a presumed monoxenous trypanosomatid isolated from humans in a murine model. Fournal of Eukaryotic Microbiology 48, 170-176.

Hennig, w. (1965). Phylogenetic systematics. Annual Review of Entomology 10, 97-116.

HigGins, D. G., DESMOND, G. \& SHARP, P. M. (1989). Fast and sensitive multiple alignments on a microcomputer. CABIOS 5, 151-153.

JiMENEZ, M.I., LOPEZ-VElez, R., MOlina, R., CANAVETE, C. \& ALVAR, J. (1996). HIV co-infection with a currently non-pathogenic flagellate. Lancet 347, 264-265.

MASLOV, D. A., LUKES, J., JIRKU, M. \& SIMPSON, L. (1996). Phylogeny of trypanosomes as inferred from the small and large subunit rRNAs: implications for the age and origin of parasitism. Molecular and Biochemical Parasitology 75, 197-205.

NOYES, H. A., MORRISON, D. A., CHANCE, M. L. \& Ellis, J. T. (2000). Evidence for a Neotropical origin of Leishmania. Memorias do Instituto Oswaldo Cruz 95, 575-578.

PACHECO, R. S., MARZOChI, M. C. A., PIRES, M. Q., BRITO, C. M. M., MAdeIRA, M. D. \& Barbosasantos, E. G. O. (1998). Parasite genotypically related to a monoxenous trypanosomatid of dog's flea causing opportunistic infection in an HIV positive patient. Memorias do Instituto Oswaldo Cruz 93, 531-537.

PIARRoux, R., Trouve, V., PRATLONG, F., MARTINi, A., LAMBERT, M. \& RIOUX, J. A. (1994). The use of isoelectric focusing on polyacrylamide gel for the enzymatic analysis of Old World Leishmania species. Transactions of the Royal Society of Tropical Medicine and Hygiene 88, 475-478.

Rioux, J. A \& LANOTte, G. (1993). Aport de la cladistique à l'analyse du genre Leishmania Ross, 1903

(Kinetoplastida; Trypanosomatidae). Corollaires écoépidémiologiques. Biosystema 8, 79-90.

Rioux, J. A., LANOTTE, G., SERRES, E., PRATLONG, F., BASTIEN, P. \& PERIERES, J. (1990). Taxonomy of Leishmania. Use of isoenzymes. Suggestions for a new classification. Annales de Parasitologie Humaine et Comparée 65, 111-125.

SAITOU, N. \& NEI, M. (1987). The neighbor joining method: A new method for reconstructing phylogenetic trees. Molecular Biology and Evolution 4, 406-425.

SCHNUR, L. F., MORSY, T. F., GITHURIE, J. I. \& JACOBSON, R. I. (1992). The status and role of novel trypanosomatids from Egypt and Kenya as parasites of man and animals. American Fournal of Tropical Medicine and Hygiene 47, 246-247.

sousa, M. A., SANTOS, S. M., SÁ-Xavier, C., Madeira, M. F., CUPOLIllo, E. \& BRAZIL, R. P. (1998). Herpetomonas sp. 
isolated from Nectomys squamypes (Mammalia:

Rodentia): molecular, biochemical and morphobiological characterisation, Third International Meeting on Molecular Epidemiology and Evolutionary Genetics of Infectious Diseases, Rio de Faneiro, 85 stevenel, L. (1917). Présence à la Martinique d'ulcération de la peau dues à Leishmania americana. Bulletin de la Société de Patholgie Exotique 10, 379-381.
TELFORD, S. R. Jr. (1995). The kinetoplastid hemoflagellates of reptiles. In Parasitic Protozoa (ed. Kreier, J. P.), 2nd Edn, Vol. 10, pp. 161-223.

Academic Press, San Diego.

THOMAZ SOCCOL, V., LANOTTE, G., RiOUX, J. A., PRATLONG, F., MARTINi-DUMAS, A. \& SERRES, E. (1993).

Monophyletic origin of the genus Leishmania Ross, 1903. Annales de Parasitologie Humaine et Comparée 68, 107-108. 